\title{
Effect of Alkali Treatment on Heavy Metals Adsorption Capacity of Sewage Sludge
}

\author{
Jianlong $\mathrm{Hu}^{1^{*}}$, Xiaosong Yang1, Linan Shao', Xuwen $\mathrm{He}^{2}$, Kunkuo Men ${ }^{2}$ \\ ${ }^{1}$ Beijing General Research Institute of Mining \& Metallurgy, Beijing, China \\ ${ }^{2}$ China University of Mining and Technology (Beijing), Beijing, China \\ Email: ${ }^{*}$ hujianlwj@126.com
}

Received December 2014

\begin{abstract}
Sewage sludge is the promising raw material for biosorbent preparation. In this work, we evaluated the heavy metals adsorption characteristics of alkali treated sewage sludge (ATSS) by equilibrium studies. The adsorption isotherms were fitted with Langmuir and Freundlich models. Comparing with untreated sewage sludge, the total adsorption capacity $\left(q_{m}\right)$ of ATSS (prepared with $0.125 \mathrm{~mol} / \mathrm{L} \mathrm{NaOH}$ ) for $\mathrm{Cd}, \mathrm{Pb}, \mathrm{Ni}$, increased by $0.51,0.70$ and $0.32 \mathrm{mmol} / \mathrm{g}$, respectively. When the $\mathrm{NaOH}$ concentration for ATSS preparation increased from $0.125 \mathrm{~mol} / \mathrm{L}$ to $0.25 \mathrm{~mol} / \mathrm{L}$, the $\mathrm{q}_{\mathrm{m}}$ of ATSS for $\mathrm{Pb}$ decreased from $1.05 \mathrm{mmol} / \mathrm{g}$ to $0.84 \mathrm{mmol} / \mathrm{g}$. However, when the $\mathrm{NaOH}$ concentration increased from $0.25 \mathrm{~mol} / \mathrm{L}$ to $7.5 \mathrm{~mol} / \mathrm{L}$, it showed increasing trend. According to the IR spectra data, the adsorption effect of biosorbent for heavy metals was mainly due to the complexation of $-\mathrm{N}-\mathrm{H}$ groups and $-\mathrm{COOH}$ groups.
\end{abstract}

\section{Keywords}

Sewage Sludge, Alkali Treatment, Heavy Metals, Adsorption

\section{Introduction}

Sewage sludge is an unavoidable by-product of wastewater treatment plants. The costs associated with sludge treatment and disposal can reach $50 \%$ of wastewater treatment plants costs [1]. Thus, techniques allowing sludge reduction and resource utilization are increasing studied. Many studies have shown that sewage sludge can adsorb substantial quantities of heavy metals in solution [2]-[4]. The biosorbent prepared with sewage sludge can remove heavy metals from wastewater by complex mechanisms including surface complexation with negatively charged biopolymers, ion exchange and physical adsorption [5]-[7]. These mechanisms are influenced by biosorbent components and operational conditions: $\mathrm{pH}$, temperature, hydraulic residence time [8], sludge age [9], feed $\mathrm{C} / \mathrm{N}$ ratio [10], dissolved organic matter [11], etc.

One of the major problems limiting the real application of biosorbent is that its adsorption capacity for heavy metals is relative low. The heavy metal adsorption capacity of biosorbent made from sewage sludge ranges from 0.01 to $0.38 \mathrm{mmol} / \mathrm{g}$ [6] [7] [12], it is lower than the commercial adsorbent [13]. The relatively low adsorption capacity of biosorbent means that more biosorbent should be used in order to insure the removal efficiency of

\footnotetext{
*Corresponding author.
}

How to cite this paper: Hu, J.L., Yang, X.S., Shao, L.N., He, X.W. and Men, K.K. (2015) Effect of Alkali Treatment on Heavy Metals Adsorption Capacity of Sewage Sludge. Journal of Geoscience and Environment Protection, 3, 33-39. 
heavy metals in wastewater, and it may produce more wasted biosorbent loaded with heavy metals. Therefore, novel preparation method should be developed in order to improve the adsorption capacity of biosorbent.

The alkali treatment was previously studied as the pretreatment method for sewage sludge anaerobic digestion [14] [15], it was proved to be an effective way to enhance the efficiency of biological hydrolysis of sewage sludge and increase methane production [15]-[17]. In addition, it was studied as extraction technique to recover useful organic material (protein, carbohydrates, etc) from sewage sludge [18]-[20]. The alkali treatment can destroy the cell walls of bacteria in sewage sludge leading to the solubilization of extracellular and intracellular materials into the aqueous phase. Thus, for sewage sludge, the alkali treatment is possible to enhance the heavy metal adsorption capacity by release of its intracellular complexation sites and chemical modification of function groups. However, to our best knowledge, the adsorption capacity of sewage sludge treated with alkali solution has not been studied. Therefore, the purpose of this study was to investigate the heavy metals adsorption capacity of alkali treated sewage sludge by equilibrium experiments. Furthermore, the effect of alkali concentration for treatment on adsorption capacity was evaluated as well.

\section{Materials and Methods}

\subsection{Materials}

The sewage sludge was obtained from a municipal wastewater treatment plant in Beijing, China. The sewage sludge was collected after mechanical dewater treatment, stored in refrigerator at $-18^{\circ} \mathrm{C}$ before use. Main characteristics of sewage sludge are listed in Table $\mathbf{1 .}$

\subsection{Methods}

\subsubsection{Preparation of Alkali Treated Sewage Sludge}

The alkali treated sewage sludge was prepared with $\mathrm{NaOH}$ solution of various concentration (range from 0.125 $7.5 \mathrm{~mol} / \mathrm{L}$ ). Sewage sludge of $25.0 \mathrm{~g}$ (approximate dry weight $4.48 \mathrm{~g}$ ) was added into conical flask containing $100 \mathrm{~mL} \mathrm{NaOH}$ solution. The suspension was agitated on a shaker at $100 \mathrm{r} / \mathrm{min}$ at $35^{\circ} \mathrm{C}$ for $12 \mathrm{~h}$. Then, to remove soluble part, the mixture was centrifuged at $6000 \times \mathrm{g}$ for $20 \mathrm{~min}$. The solid after centrifugation was collected, added into deionized water and repeated the centrifugation process for twice in order to remove the dissolved impurities and residual $\mathrm{NaOH}$. The final pellet left was suspended in deionized water, neutralized with nitric acid solution, diluted to $100 \mathrm{ml}$ with deionized water, and stored at $4^{\circ} \mathrm{C}$ before use. This suspension was the alkali treated sewage sludge used in this study.

\subsubsection{Adsorption Equilibrium Experiment}

Heavy metal adsorption onto alkali treated sewage sludge was evaluated with three typical metals in wastewater: Cadmium $\left(\mathrm{Cd}^{2+}\right)$, nickel $\left(\mathrm{Ni}^{2+}\right)$, and lead $\left(\mathrm{Pb}^{2+}\right)$. All stock solution containing heavy metal were prepared by dissolving heavy metal nitrate salts in deionized water. The $\mathrm{pH}$ of heavy metals working solution were adjusted to 5.0 using $0.1 \mathrm{~mol} / \mathrm{L} \mathrm{NaOH}$ solution and $0.1 \mathrm{~mol} / \mathrm{L}$ nitric acid solution in order to prevent precipitation of heavy metals.

Equilibrium sorption experiments were conducted by adding $10 \mathrm{~mL}$ biosorbent to $90 \mathrm{ml}$ heavy metal solution. The mixture was agitated on a rotary shaker at $150 \mathrm{rpm}$ at $25^{\circ} \mathrm{C}$ for $24 \mathrm{~h}$. Then the mixture was centrifuged at $6000 \times \mathrm{g}$ for $20 \mathrm{~min}$, and the supernatant was filtered with cellulose nitrate membrane $(0.45 \mu \mathrm{m}$ pore size $)$. The filtrate was acidified with concentrated nitric acid and stored at $4{ }^{\circ} \mathrm{C}$ before analysis. Blanks without biosorbent were run simultaneously as control. All experimental were run in triplicate. The heavy metals concentration were measured with inductively coupled plasma-atomic emission spectrometry (ICP-AES).

Adsorption experimental data were fitted to the models of Langmuir and Freundlich (Equations (1) and (2), respectively).

$$
\begin{gathered}
q_{e}=\frac{K_{L} q_{m} C_{e}}{1+K_{L} C_{e}} \\
q_{e}=K_{F} C_{e}^{\frac{1}{n}}
\end{gathered}
$$

where $C_{e}(\mathrm{mmol} / \mathrm{L})$ is the heavy metal ions concentration at equilibrium, $q_{e}(\mathrm{mmol} / \mathrm{g})$ is the amount of adsorbed metal ions per unit dry weight of biosorbent, $q_{m}(\mathrm{mmol} / \mathrm{g})$ is the total adsorption capacity of adsorbent. $K_{L}, K_{F}$ 
Table 1. Main characteristics of sewage sludge.

\begin{tabular}{|c|c|}
\hline Property/element & Sewage Sludge \\
\hline Dry matter (wt $\%)$ & 17.9 \\
\hline Carbon (wt $\%{ }^{\mathrm{d}}$ ) & 28.1 \\
\hline Hydrogen $\left(w{ }^{0}{ }^{d}\right)$ & 4.2 \\
\hline Oxygen $\left(w t \%{ }^{d}\right)$ & 17.9 \\
\hline Nitrogen $\left(w t^{\circ}{ }^{d}\right)$ & 3.8 \\
\hline $\mathrm{P}\left(\mathrm{wt} \%{ }^{\mathrm{d}}\right)$ & 1.2 \\
\hline Sulfur $\left(w t \%{ }^{d}\right)$ & 0.8 \\
\hline Calcium $\left(\mathrm{wt} \%{ }^{\mathrm{d}}\right)$ & 3.5 \\
\hline Magnesium (wt $\%{ }^{\mathrm{d}}$ ) & 5.1 \\
\hline
\end{tabular}

${ }^{d}$ represents dry weight element composition.

and $\mathrm{n}$ are the isotherm constants.

The adsorption capacity $\left(q_{e}\right)$ was calculated as Equation (3).

$$
q_{e}=\frac{C_{o} V_{1} C_{e}\left(V_{1}+V_{2}\right)}{m}
$$

where $C_{o}\left(\mathrm{mmol} \cdot \mathrm{L}^{-1}\right)$ is the initial heavy metal concentration of working solution, $C_{e}\left(\mathrm{mmol} \cdot \mathrm{L}^{-1}\right)$ is the equilibrium concentration of heavy metal, $V_{1}(\mathrm{~L})$ is the volume of working solution, $V_{2}(\mathrm{~L})$ is the volume of biosorbent suspension, $m(\mathrm{~g})$ is the dry weight of biosorbent contained in biosorbent suspension. The value of $\mathrm{m}$ is measured for every kind of biosorbent suspension.

\section{Results and Discussion}

\subsection{Adsorption Isotherms of Alkali Treated Sewage Sludge}

Equilibrium sorption studies were performed to explore heavy metal adsorption capacity of the biosorbent. The adsorption isotherms for sewage sludge and alkali treated sewage sludge were shown in Figure 1 and Figure 2, respectively; $q_{e}$ represented the amount of metal ion adsorbed per unit weight of biomass and $C_{e}$ represented the metal ion concentration remaining in solution at equilibrium.

The initial $\mathrm{pH}$ value was 5.0 for all working solutions in order to prevent precipitation of heavy metals, the $\mathrm{pH}$ was not controlled during the equilibrium experiment. The final $\mathrm{pH}$ of heavy metal working solution after adsorption was in the range of $5.9-6.3$ (results are not given). According to previous study [22], at the $\mathrm{pH}$ range of $6, \mathrm{~Pb}^{2+}$ accounts for about $98.6 \%$ of total lead, $\mathrm{Cd}^{2+}$ and $\mathrm{Ni}^{2+}$ accounts for $100 \%$ of total cadmium and total nickel, respectively. Thus, the precipitation of heavy metal ions can be neglected in the adsorption process.

For both alkali treated sewage sludge and sewage sludge, the Langmuir model yielded a little better fit than the Freundlich model (Table 2), and the good agreement with experimental data suggests that monolayer adsorption existed for the experiment, which is consistent with adsorption process between heavy metals and other biosorbent such as sugar beet pulp [23], dried activated sludge [24]. In addition, comparing with sewage sludge, the $q_{m}$ value of alkali treated sewage sludge for $\mathrm{Cd}, \mathrm{Pb}, \mathrm{Ni}$, increased by $0.51,0.70$ and $0.32 \mathrm{mmol} / \mathrm{g}$, respectively. The higher $q_{m}$ value of alkali treated sewage sludge indicates that the maximum heavy metal adsorption capacity of sewage sludge was significantly enhanced by alkali treatment.

For alkali treated sewage sludge, $q_{m}$ and $K_{L}$ values followed the order: $\mathrm{Pb}^{2+}>\mathrm{Cd}^{2+}>\mathrm{Ni}^{2+}$. This trend indicates the bonding affinity of alkali treated sewage sludge to heavy metals is in the order of $\mathrm{Pb}^{2+}>\mathrm{Cd}^{2+}>\mathrm{Ni}^{2+}$.

\subsection{Effect of Alkali Concentration on Adsorption Capacity of Sewage Sludge}

The alkali treatment can significantly enhance the heavy metal adsorption capacity of sewage sludge, and the 


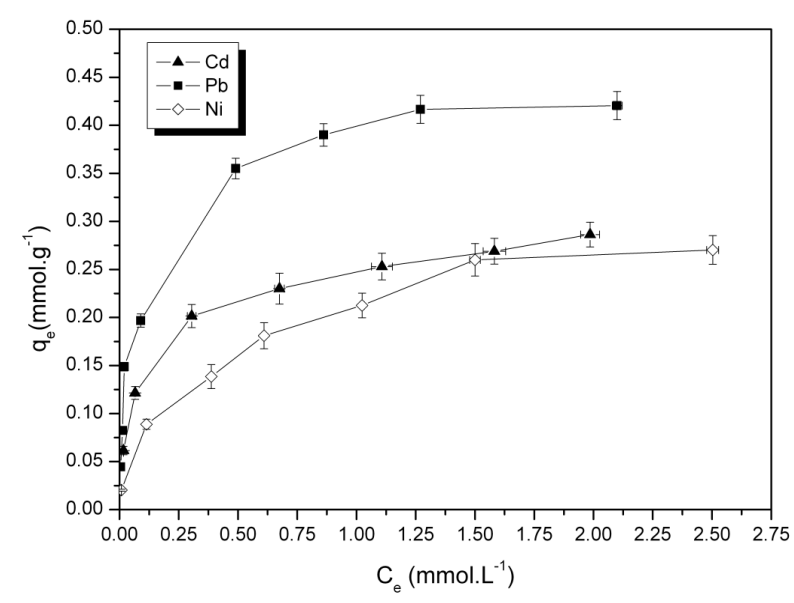

Figure 1. Heavy metals biosorption isotherms for sewage sludge. Date points are the average of triplicate bottles and the error bars represent standard deviation.

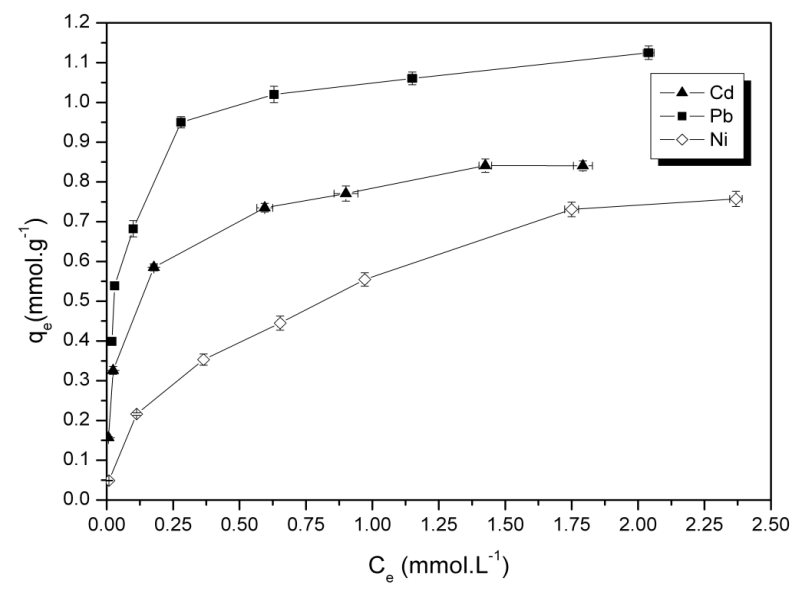

Figure 2. Heavy metals biosorption isotherms for alkali treated sewage sludge (prepared with $0.125 \mathrm{~mol} / \mathrm{L} \mathrm{NaOH}$ ). Date points are the average of triplicate bottles and the error bars represent standard deviation.

Table 2. Heavy metals adsorption isotherms parameters for sewage sludge prior to and after alkali treatment (prepared with $0.125 \mathrm{~mol} / \mathrm{L} \mathrm{NaOH})$.

\begin{tabular}{lccccccc}
\hline & & \multicolumn{3}{c}{ Langmuir model } & \multicolumn{4}{c}{ Freundlich model } \\
\hline \multirow{2}{*}{ adsorbent } & adsorbate & $\mathrm{q}_{\mathrm{m}}\left(\mathrm{mmol} \cdot \mathrm{g}^{-1}\right)$ & $\mathrm{K}_{\mathrm{L}}\left(\mathrm{L} \cdot \mathrm{mmol}^{-1}\right)$ & $\mathrm{R}^{2}$ & $\mathrm{n}$ & $\mathrm{K}_{\mathrm{F}}\left(\mathrm{mmol} \cdot \mathrm{L}^{-1 / \mathrm{n}} \cdot \mathrm{L}^{1 / n} \cdot \mathrm{g}^{-1}\right)$ & $\mathrm{R}^{2}$ \\
\hline \multirow{3}{*}{ Sewage sludge } & $\mathrm{Cd}^{2+}$ & 0.25 & 1.17 & 0.986 & 3.25 & 0.35 & 0.962 \\
& $\mathrm{~Pb}^{2+}$ & 0.35 & 3.50 & 0.982 & 0.44 & 2.68 & 0.936 \\
& $\mathrm{Ni}^{2+}$ & 0.20 & 0.52 & 0.991 & 0.21 & 2.15 & 0.984 \\
& $\mathrm{Cd}^{2+}$ & 0.76 & 21.14 & 0.993 & 0.80 & 3.50 & 0.947 \\
\multirow{3}{*}{ Alkali treated sludge } & $\mathrm{Pb}^{2+}$ & 1.05 & 35.09 & 0.970 & 1.07 & 4.69 & 0.929 \\
& $\mathrm{Ni}^{2+}$ & 0.52 & 3.18 & 0.992 & 0.55 & 2.04 & 0.990 \\
\hline
\end{tabular}

effect of $\mathrm{NaOH}$ concentration for alkali treatment on lead adsorption capacity was studied, as shown in Figure 3.

For all biosorbent prepared with different $\mathrm{NaOH}$ solution, the equilibrium data were well described with 
Langmuir model as shown in Table 3, which was consistent with previous study. The principal components in sewage sludge are polysaccharides and proteins. Alkali treatment (mainly $\mathrm{NaOH}$ ) is an effective carbohydrate and protein extraction method. $\mathrm{NaOH}$ ionizes charged groups in proteins and polysaccharides [18]. The ionized functional groups of protein and polysaccharides, such as amino group, hydroxyl group, carboxyl group, complexes with heavy metals. Thus, comparing with sewage sludge before treatment, the $q_{m}$ value of treated sewage sludge prepared by $0.125 \mathrm{~mol} / \mathrm{L} \mathrm{NaOH}$ solution increased by $0.7 \mathrm{mmol} / \mathrm{g}$. However, when the $\mathrm{NaOH}$ concentration increased from $0.125 \mathrm{~mol} / \mathrm{L}$ to $0.25 \mathrm{~mol} / \mathrm{L}$, the $q_{m}$ of biosorbent decreased from $1.05 \mathrm{mmol} / \mathrm{g}$ to 0.84 $\mathrm{mmol} / \mathrm{g}$. This trend may be due to that the $\mathrm{NaOH}$ solution with higher concentration hydrolyzed and disintegrated part of protein and polysaccharides in treated sewage sludge [25]. Nevertheless, when the $\mathrm{NaOH}$ concentration continued to increase from $0.25 \mathrm{~mol} / \mathrm{L}$ to $7.5 \mathrm{~mol} / \mathrm{L}$, the $q_{m}$ values of treated sewage sludge showed increasing trend. This increasing trend indicates that the $\mathrm{NaOH}$ solution with higher concentration leads to the hydrolysis of bacteria cell of sewage sludge [26]. Then, more intracellular complexation sites expose to heavy metals.

\subsection{Functional Groups Analysis}

The IR spectra obtained from sewage sludge prior to and after alkali treatment (Figure 4) were used to analysis the presence of main adsorption functional groups. For alkali treated sewage sludge prior to lead adsorption, the peak at $1657 \mathrm{~cm}^{-1}$ was attributed to the stretching vibration of $\mathrm{C}=\mathrm{O}$ and $\mathrm{C}-\mathrm{N}$ groups. The peak at $1562 \mathrm{~cm}^{-1}$ was due to the $\mathrm{N}-\mathrm{H}$ bending vibration and $\mathrm{C}-\mathrm{N}$ stretching vibration. These groups above were the characteristics spectra of protein. The peak at $1416 \mathrm{~cm}^{-1}$ was assigned to the stretching vibration of $\mathrm{C}=\mathrm{O}$ and deformation vibration of $\mathrm{OH}$. The peak at $1014 \mathrm{~cm}^{-1}$ was attributed to the stretching vibration of $\mathrm{OH}$.

Comparing with the IR spectra of alkali treated sewage sludge prior to and after $\mathrm{Pb}^{2+}$ adsorption, the peak shapes were similar, and no new adsorption peak was observed. It indicated that the material structure did not change after $\mathrm{Pb}^{2+}$ adsorption. After $\mathrm{Pb}^{2+}$ adsorption, the peak at $1570 \mathrm{~cm}^{-1}$ was moved for $20 \mathrm{~cm}^{-1}$ toward infra-

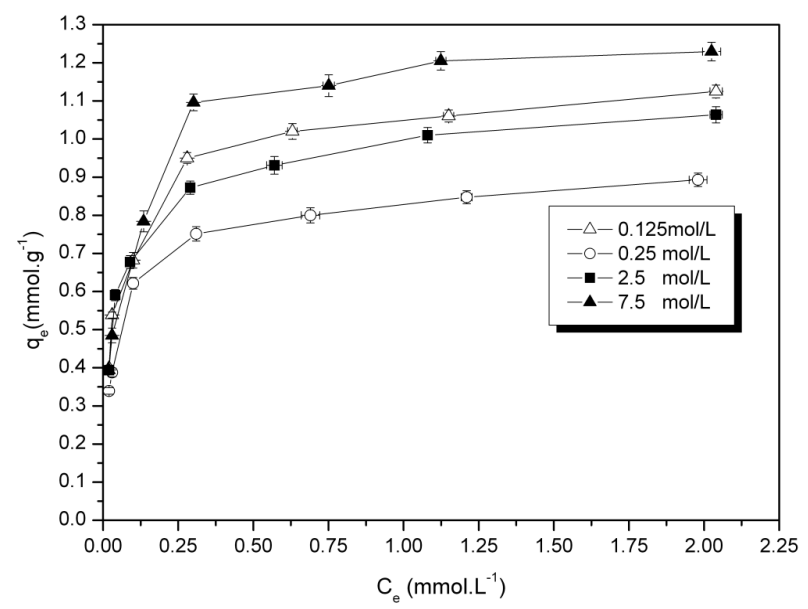

Figure 3. Adsorption isotherms of $\mathrm{Pb}^{2+}$ for biosorbent treated with $\mathrm{NaOH}$ solution of different concentration.

Table 3. $\mathrm{Pb}^{2+}$ adsorption isotherms parameters for various alkali treated biosorbent.

\begin{tabular}{ccccccc}
\hline & \multicolumn{3}{c}{ Langmuir model } & \multicolumn{3}{c}{ Freundlich model } \\
\hline adsorbate & $\mathrm{qm}\left(\mathrm{mmol} \cdot \mathrm{g}^{-1}\right)$ & $\mathrm{KL}\left(\mathrm{L} \cdot \mathrm{mmol}^{-1}\right)$ & $\mathrm{R}^{2}$ & $\mathrm{n}$ & $\mathrm{K}_{\mathrm{F}}\left(\mathrm{mmol} \cdot \mathrm{L}^{(1-1 / \mathrm{n})} \cdot \mathrm{g}^{-1}\right)$ & $\mathrm{R}^{2}$ \\
\hline $0.125 \mathrm{~mol} / \mathrm{L} \mathrm{NaOH}$ treated & 1.05 & 35.09 & 0.970 & 1.07 & 4.69 & 0.929 \\
$0.25 \mathrm{~mol} / \mathrm{L} \mathrm{NaOH}$ treated & 0.84 & 22.81 & 0.986 & 0.85 & 4.81 & 0.927 \\
$2.5 \mathrm{~mol} / \mathrm{L} \mathrm{NaOH}$ treated & 1.00 & 33.27 & 0.983 & 1.01 & 5.08 & 0.917 \\
$7.5 \mathrm{~mol} / \mathrm{L} \mathrm{NaOH}$ treated & 1.17 & 35.48 & 0.981 & 1.20 & 3.98 & 0.932 \\
\hline
\end{tabular}




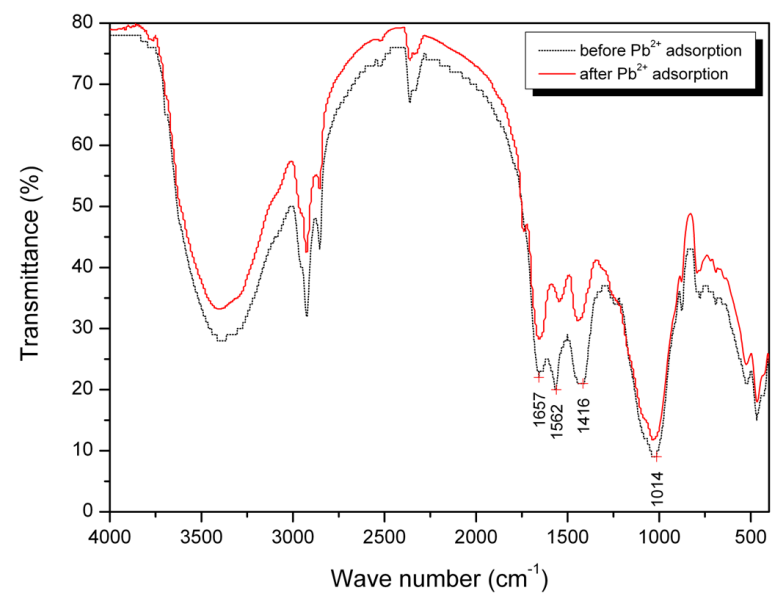

Figure 4. IR spectra of untreated sewage sludge and alkali treated sewage sludge.

red region, it was due to the complexation of $\mathrm{Pb}^{2+}$ and $\mathrm{N}-\mathrm{H}$ group. In addition, the peak at $1408 \mathrm{~cm}^{-1}$ was moved for $32 \mathrm{~cm}^{-1}$ toward infrared region, it was due to $\mathrm{Pb}^{2+}$ binding with -COOH group. Thus, the main function groups works in the heavy metal adsorption process was $\mathrm{N}-\mathrm{H}$ group and $\mathrm{COOH}$ group. These IR spectra data were similar to results of various activated samples obtained by Laurent et al. [12] [21].

\section{Conclusion}

The alkali treatment is an effective biosorbent preparation method to improve the maximum adsorption capacity of sewage sludge. The alkali treated sewage sludge achieved 1.6 - 2 fold higher adsorption capacity than untreated sewage sludge. The bonding affinity of alkali treated sewage sludge to heavy metals was in the order of $\mathrm{Pb}^{2+}>\mathrm{Cd}^{2+}>\mathrm{Ni}^{2+}$. The increase of heavy metal adsorption capacity was due to the complexation effect of more ionized functional groups formed in the alkali treatment. Furthermore, the alkali treatment leads to hydrolysis of bacteria cell of sewage sludge, and make more intracellular complexation sites expose to heavy metals. Further work is being conducted to determine the suitable operational conditions for usage of alkali treated sewage sludge.

\section{Acknowledgements}

This research was supported by National Natural Science Foundation of China project 51404028 and Beijing General Research Institute of Mining \& Metallurgy Research Foundation project YJ-2014-17.

\section{References}

[1] Apples, L., Baeyens, J., Degreve, J. and Dewil, R. (2008) Principles and Potential of the Anaerobic Digestion of Waste-Activated Sludge. Progress in Energy and Combustion Science, 34, 755-781. http://dx.doi.org/10.1016/j.pecs.2008.06.002

[2] Li, W.H., Yue, Q.Y., Gao, B.Y., Wang, X.J., Qi, Y.F., Zhao, Y.Q. and Li, Y.J. (2011) Preparation of Sludge-Based Activated Carbon Made from Paper Mill Sewage Sludge by Steam Activation for Dye Wastewater Treatment. Desalination, 278, 179-185. http://dx.doi.org/10.1016/j.desal.2011.05.020

[3] Gascó, G., Méndez, A. and Gascó, J.M. (2005) Preparation of Carbon-Based Adsorbents from Sewage Sludge Pyrolysis to Remove Metals from Water. Desalination, 180, 245-251. http://dx.doi.org/10.1016/j.desal.2005.01.006

[4] Otero, M., Rozada, F., Morán, A., Calvo, L.F. and García, A.I. (2009) Removal of Heavy Metals from Aqueous Solution by Sewage Sludge Based Sorbents: Competitive Effects. Desalination, 239, 46-57. http://dx.doi.org/10.1016/j.desal.2008.03.005

[5] Veglio, F. and Beolchini, F. (1997) Removal of Metals by Biosorption: A Review. Hydrometallurgy, 44, 301-316. http://dx.doi.org/10.1016/S0304-386X(96)00059-X

[6] Kim, D.W., Cha, D.K., Wang, J. and Huang, C.P. (2002) Heavy Metal Removal by Activated Sludge: Influence of 
Nocardia amarae. Chemosphere, 46, 137-142. http://dx.doi.org/10.1016/S0045-6535(00)00598-1

[7] Laurent, J., Casellas, M. and Dagot, C. (2009) Heavy Metals Uptake by Sonicated Activated Sludge: Relation with Floc Surface Properties. Journal of Hazardous Materials, 162, 652-660. http://dx.doi.org/10.1016/j.jhazmat.2008.05.066

[8] Özbelge, T.A., Özbelge, H.A. and Tursun, M. (2005) Effects of Hydraulic Residence Time on Metal Uptake by Activated Sludge. Chemical Engineering and Processing, 44, 23-32. http://dx.doi.org/10.1016/j.cep.2004.04.004

[9] Arican, B., Gokcay, C.F. and Yetis, U. (2002) Mechanistics of Nickel Sorption by Activated Sludge. Process Biochemistry, 37, 1307-1315. http://dx.doi.org/10.1016/S0032-9592(02)00015-8

[10] Yuncu, B., Sanin, F.D. and Yetis, U. (2006) An Investigation of Heavy Metal Biosorption in Relation to C/N Ratio of Activated Sludge. Journal of Hazardous Materials, 137, 990-997. http://dx.doi.org/10.1016/j.jhazmat.2006.03.020

[11] Wang, J., Huang, C.P., Allen, H.E., Poesponegoro, I., Poesponegoro, H. and Takiyama, L.R. (1999) Effects of Dissolved Organic Matter and pH on Heavy Metal Uptake by Sludge Particulates Exemplified by Copper(II) and Nickel(II): Three-Variable Model. Water Environment Research, 71, 139-147. http://dx.doi.org/10.2175/106143099X121517

[12] Laurent, J., Casellas, M., Carrere, H. and Dagot, C. (2011) Effect of Thermal Hydrolysis on Activated Sludge Solubilization, Surface Properties and Heavy Metals Biosorption. Chemical Engineering Journal, 166, 842-849. http://dx.doi.org/10.1016/j.cej.2010.11.054

[13] Vaughan, T., Seo, C.W. and Marshall, W.E. (2001) Removal of Selected Metal Ions from Aqueous Solution Using Treated Corncobs. Bioresource Technology, 78, 133-139. http://dx.doi.org/10.1016/S0960-8524(01)00007-4

[14] Li, H., Jin, Y.Y., Mahar, R.B., Wang, Z.Y. and Nie, Y.F. (2008) Effects and Model of Alkaline Waste Activated Sludge Treatment. Bioresource Technology, 99, 5140-5144. http://dx.doi.org/10.1016/j.biortech.2007.09.019

[15] Dogan, I. and Dilek Sanin, F. (2009) Alkaline Solubilization and Microwave Irradiation as a Combined Sludge Disintegration and Minimization Method. Water Research, 43, 2139-2148. http://dx.doi.org/10.1016/j.watres.2009.02.023

[16] Wilson, C.A. and Novak, J.T. (2009) Hydrolysis of Macromolecular Components of Primary and Secondary Wastewater Sludge by Thermal Hydrolytic Pretreatment. Water Research, 43, 4489-4498. http://dx.doi.org/10.1016/j.watres.2009.07.022

[17] Lin, J.G., Ma, Y.S. and Huang, C.C. (1998) Alkaline Hydrolysis of the Sludge Generated from a High-Strength, Nitrogenous-Wastewater Biological-Treatment Process. Bioresource Technology, 65, 35-42. http://dx.doi.org/10.1016/S0960-8524(98)00028-5

[18] Garcia Becerra, F.Y., Acosta, E.J. and Grant Allen, D. (2010) Alkaline Extraction of Wastewater Activated Sludge Biosolids. Bioresource Technology, 101, 6972-6980. http://dx.doi.org/10.1016/j.biortech.2010.04.021

[19] Liu, H. and Fang, H.H.P. (2002) Extraction of Extracellular Polymeric Substances(EPS) of Sludge. Journal of Biotechnology, 95, 249-256. http://dx.doi.org/10.1016/S0168-1656(02)00025-1

[20] Sheeng, G. and Yu, Z. (2005) Extraction of Extracellular Polymeric Substances from the Photosynthetic Bacterium Rhodopseudomonas acidophila. Applied Microbiology and Biotechnology, 67, 125-130. http://dx.doi.org/10.1007/s00253-004-1704-5

[21] Laurent, J., Pieera, M., Caasellas, M. and Dagot, C. (2009) Fate of Cadmium in Activated Sludge after Changing Its Physicochemical Properties by Thermal Treatment. Chemosphere, 77, 771-777. http://dx.doi.org/10.1016/i.chemosphere.2009.08.024

[22] Comte, S., Guibaud, G. and Baudu, M. (2008) Biosorption Properties of Extracellular Polymeric Substances (EPS) towards $\mathrm{Cd}, \mathrm{Cu}$ and $\mathrm{Pb}$ for Different $\mathrm{pH}$ Values. Journal of Hazardous Materials, 151, 185-193. http://dx.doi.org/10.1016/j.jhazmat.2007.05.070

[23] Reddad, Z.C., Gerente, C., Aandres, Y. and Cloirec, P.L. (2002) Adsorption of Several Metal Ions onto a Low-Cost Biosorbent: Kinetic and Equilibrium Studies. Environmental Science \& Technology, 36, 2067-2073. http://dx.doi.org/10.1021/es0102989

[24] Wang, X.J., Xia, S.Q., Chen, L., Zhao, J.F., Chovelon, J.M. and Nicole, J.R. (2006) Biosorption of Cadmium(II) and Lead(II) Ions from Aqueous Solutions onto Dried Activated Sludge. Journal of Environmental Sciences, 18, 840-844.

[25] McSwain, B.S., Irvine, R.L., Hausner, M. and Wilderer, P.A. (2005) Composition and Distribution of Extracellular Polymeric Substances in Aerobic Flocs and Granular Sludge. Applied and Environmental Microbiology, 71, 1051-1057. http://dx.doi.org/10.1128/AEM.71.2.1051-1057.2005

[26] Brown, M.J. and Lester, J.N. (1980) Comparison of Bacterial Extracellular Polymer Extraction Methods. Applied and Environmental Microbiology, 40, 179-185. 